Syntax Literate : Jurnal Ilmiah Indonesia p-ISSN: 2541-0849

e-ISSN : 2548-1398

Vol. 6, No. 2, Februari 2021

\title{
NGABATIK: APLIKASI PENGENALAN MOTIF BATIK NGAWI BERBASIS ANDROID
}

\author{
Devie Febriansari dan Idam Ragil Widianto Atmojo \\ Universitas Sebelas Maret, Bappelitbang Ngawi \\ Email: febriansaridevie@student.uns.ac.id dan idamragil@ fkip.uns.ac.id
}

\section{Abstract}

Batik is one of the cultural herritage that has been designated by UNESCO as a Cultural Heritage Humanity's Oral and Non-material Masterpieces of the Oral and Intangible Heritage of Humanity) since October 2009. Art Batik is the art over the cloths to clothe the beginning only used by the family empires only. The advancement of science in the field of information and communication technology, especially the use of handheld devices Android smartphone has changed the perspective and lifestyle in carrying out daily activities. This impacted on the traditional arts activities. The public's decreasing interest to learn or just to know about batik motifs behind these problems, and then this application presents to integrate scientific advances in technology by loading traditional content such as Batik, especially in Ngawi Regency and the people can preserve it. This application created to introduce Ngawi Batik motifs, and people can understand the meaning of Batik motifs and can be accessed anywhere and anytime via an android smartphone. The purpose of this study is to design, create and test ngabatik application so that the product of digital batik motif recognition application based on android application that can be functioned properly throughout both the system and the usefulness of its features. The method used is a modification of the procedural model that describes the procedural stages that must be followed in producing a particular product. The results of user satisfaction by using questionnaires show a user satisfaction rate of $80.9 \%$ which means that the application is very satisfying in the eyes of its users.

Keywords: android; batik; application; ngawi

\begin{abstract}
Abstrak
Batik merupakan salah satu warisan budaya yang telah ditetapkan oleh UNESCO sebagai Warisan Kemanusiaan untuk Budaya Lisan dan Non-Bendawi (Masterpieces of the Oral and Intangible Heritage of Humanity) sejak Oktober 2009. Kesenian batik adalah kesenian diatas kain untuk dijadikan pakaian yang awal mulanya hanya dipakai oleh keluarga kerajaan saja. Kemajuan ilmu pengetahuan di bidang teknologi informasi dan komunikasi terutama penggunaan perangkat genggam smartphone android telah mengubah cara pandang dan gaya hidup dalam menjalankan kegiatan sehari-hari. Hal ini berdampak pula pada kegiatan kesenian yang bersifat tradisional. Semakin berkurangnya minat dari masyarakat untuk belajar atau sekedar mengenal tentang motif batik melatar
\end{abstract}


belakangi permasalahan tersebut, aplikasi ini hadir untuk memadukan kemajuan ilmu pengetahuan dalam bidang teknologi dengan memuat konten yang bersifat tradisional seperti batik khususnya di Kabupaten Ngawi agar masyarakat dapat melestarikannya. Aplikasi ini dibuat untuk memperkenalkan motif batik Ngawi dan juga memhami setiap maknanya yang dapat diakses dimana saja dan kapan saja melalui smartphone android. Tujuan dari studi ini adalah merancang, membuat dan menguji aplikasi NgaBatik sehingga didapat produk aplikasi pengenalan motif batik digital berbasis aplikasi android yang dapat difungsikan dengan baik keseluruhan baik sistem dan kegunaan fiturnya. Metode yang digunakan adalah modifikasi model prosedural yang menjabarkan tahapan prosedural yang harus diikuti dalam menghasilkan produk tertentu. Hasil kepuasan pengguna dengan menggunakan kuisioner menunjukkan tingkat kepuasan pengguna sebesar 80,9\% yang berarti aplikasi sangatlah memuaskan dimata penggunanya.

Kata Kunci: android; batik; aplikasi; ngawi

Coresponden Author

Email: febriansaridevie@student.uns.ac.id Artikel dengan akses terbuka dibawah lisensi

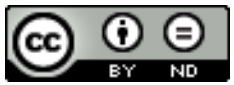

\section{Pendahuluan}

Batik adalah seni gambar diatas kain untuk pakaian yang dibuat dengan teknik resist menggunakan material lilin. Kata batik berasal dari bahasa Jawa yang berarti menulis. Teknik membatik telah dikenal sejak ribuan tahun yang silam. Tidak ada keterangan sejarah yang cukup jelas tentang asal usul batik. Ada yang menduga teknik ini berasal dari bangsa Sumeria, kemudian dikembangkan di Jawa setelah dibawa oleh para pedagang India. Batick, batic, bathik, battik, batique dan batek serta batix adalah sebutan lain kain batik. Saat ini batik bisa ditemukan di banyak negara seperti Indonesia, Malaysia, Thailand, India, Sri Lanka dan Iran. Selain di Asia, batik juga sangat populer di beberapa negara di benua Afrika. Walaupun demikian, batik yang sangat terkenal di dunia adalah batik yang berasal dari Indonesia (Arifianto, 2011).

Batik menjadi salah satu budaya milik Negara Indonesia yang perlu dijaga oleh setiap masyarakat Negara Indonesia. Salah satu budaya yang memperlihatkan seni rupa berupa corak atau motif yang dilakukan terhadap kain ini, telah ada sejak zaman kerajaan Majapahit pada akhir abad ke-18 atau awal abad ke-19 dan menyebar kepada kerajaan lainnya (Anisa \& Rachmaniar, 2019).

Setiap daerah di Indonesia mempunyai corak batik yang berbeda-beda dikarenakan pengaruh budaya masyarakat setempat. Corak batik daerah Jawa Tengah seperti Solo, Yogyakarta dan Pekalongan lebih banyak bermotif flora dengan alur yang rapat dengan warna-warna gelap seperti hitam ataupun coklat tua, berbeda dengan corak batik daerah Madura terutama Sumenep yang mengkombinasikan antara flora dan fauna dengan dominasi warna merah (Handriyantini, 2009). Semenjak diakuinya batik oleh UNESCO pada tahun 2009, budaya batik semakin dicintai oleh masyarakat Negara 
Indonesia karena mampu memberikan sebuah kebanggaan tersendiri bagi masyarakat Indonesia (Rosyadi et al., 2020).

Di Indonesia, batik dibuat di berbagai daerah. Setiap daerah mempunyai keunikan dan ciri khas masing-masing,baik dalam ragam hias tata warnanya. Namun demikian, dapat dilihat adanya persamaan maupun perbedaan antara batik diberbagai daerah tersebut, hal ini akan menambah pesona dan kekayaan akan seni Budaya bangsa (Parmono, 2017). Motif Batik Tradisional kebanyakan bersifat monumental dari alam sekelilingnya, imajinasi atau agama/kepercayaan dari senimannya yang biasanya anonim (sesuai dengan sifat bangsa Jawa/Indonesia) yang selalu tidak mau/tidak boleh menonjolkan diri karyanya, dan bersikap andap' asor (Parmono, 2013).

Salah satu kabupaten yang memiliki kesenian batik adalah Kabupaten Ngawi. Kabupaten Ngawi mulai menggiatkan kembali kesenian batik untuk melestarikan motifmotif khas turun temurun dari leluhur yang sempat hampir punah (Wibowo et al., 2016). Motif tersebut mencerminkan mengenai alam dan sosial budaya yang terjadi di Kabupaten Ngawi, diantaranya motif bambu, motif padi, motif pohon jati, motif manusia purba, motif kali tumpuk dan masih banyak motif-motif yang terus dikembangkan oleh masyarakat atau belum ter-eksplore untuk digali lebih mendalam. Motif-motif yang selama ini dikembangkan di Kabupaten Ngawi sendiri hanya berdasarkan kepada potensi alam saja, dan belum banyak mengembangkan potensi mengenai seni budaya yang ternyata sangatlah kaya (Istiqomah, 2020).

Masyarakat pada saat ini belum mengetahui betul tentang batik yang ada di Indonesia. Batik merupakan warisan leluhur Indonesia yang telah diakui oleh UNESCO, namun banyak keterbatasan dalam pengenalan batik yang ada di daerah Indonesia (Ardhianto, 2013). Pengenalan terhadap motif batik pada saat ini hanya dapat dilihat dengan cara datang ke museum atau dengan menyelenggarakan pameran galeri motif batik. Galeri batik dapat berfungsi sebagai tempat pameran atau dapat berfungsi untuk tempat memperdagangkan batik. Namun ada keterbatasan dalam penyelenggaraan galeri batik yaitu memerlukan ketersediaan tempat serta harus mendatangkan kain batik yang seringkali sudah berumur sehingga rentan terhadap kerusakan (Jasmadi, 2008).

Teknologi digital kini tersedia di hampir semua segmen kehidupan sehari-hari (Stojšić et al., 2019), dan terdapat pula beberapa aplikasi tentang batik yang sudah dikembangkan secara komersil atau berdasarkan penelitian ilmiah akademik seperti Tugas Akhir, Skripsi, Jurnal, dan sebagainya. Fitur utama dari aplikasi ini adalah untuk mengenal jenis-jenis batik di Kabupaten Ngawi, terdapat pula beberapa fitur tambahan yang ditawarkan untuk lebih mempermudah pengguna mempelajari berbagai macam motif batik dan cara membuatnya.

Aplikasi permainan interaktif belajar membatik sendiri sudah cukup banyak diciptakan, namun dari sekian banyak permainan yang sudah ada tidak semua menyajikan pilihan permainan dan pembelajaran menggambar dan informasi mengenai jenis-jenis batik tetapi belum berbasis android atau tersedia di playstore. Kebanyakan hanya menyajikan satu pilihan yaitu belajar membatik atau sekedar mengenal batik secara umum. Berikut beberapa aplikasi yang menyajikan pembelajaran menulis huruf 
dengan mengikuti pola, meliputi Ayo Mbatik (Kusumawardhani, 2013), Game Edukasi Ayo Membatik (Rauhandi, 2011), dan Belajar Mengenal Batik Interaktik (Pranowo, 2011).

Studi ini bertujuan untuk membuat produk aplikasi tertentu dengan menggunakan pendekatan Research and Development (R\&D) (Hanafi, 2017). Tujuan lain dari studi ini adalah merancang, membuat dan menguji aplikasi NgaBatik sehingga didapat produk aplikasi pengenalan motif batik digital berbasis aplikasi android yang dapat difungsikan dengan baik keseluruhan baik sistem dan kegunaan fiturnya. Pengujian yang dilakukan terhadap NgaBatik versi 1.0 menggunakan blackbox testing untuk memastikan fiturfitur dalam aplikasi software dapat berfungsi dengan baik dan memindai eror sehingga dapat dilakukan perbaikan sebelum aplikasi digunakan. Aplikasi ini dapat membantu pengguna mengenal budaya batik yang terdapat di Kabupaten Ngawi tanpa harus melakukan browsing di internet dan lainnya.

\section{Metode Penelitian}

Metode yang digunakan adalah modifikasi model prosedural yang menjabarkan tahapan prosedural yang harus diikuti dalam menghasilkan produk tertentu. Aplikasi permainan pengenalan sejarah dan jenis batik di Kabupaten Ngawi ini diberi nama NgaBatik. Aplikasi Ngabatik merupakan sebuah aplikasi pengenalan motif batik Ngawi yang didalamnya terdapat informasi mengenai sejarah, jenis-jenis batik yang terdapat di Kabupaten Ngawi, alat dan bahan apa saja yang digunakan saat membuat batik, dan lain sebagainya.

Pada aplikasi ini terdapat menu belajar meliputi sejarah batik, jenis-jenis batik, galeri motif batik di Kabupaten Ngawi beserta makna dari setiap motif, cara pembuatan kain batik, dan latihan soal pembelajaran. Juga terdapat permainan membatik sebagai sarana yang interaktif dalam belajar menyusun motif batik dari potongan-potongan puzzle yang nantinya akan terbentuk sebuah motif.

1. Gambaran Umum Sistem

Prinsip kerja sistem secara umum aplikasi ini adalah semua pengguna dapat mengetahui berbagai motif yang ada di Kabupaten Ngawi yang sangat kurang terekspose dikalangan masyarakat.

2. Perancangan Sistem

Dalam perancangan aplikasi NgaBatik, penulis menggunakan desain permodelan sistem UML atau Unified Modelling Language sebagai media untuk menyampaikan rancangan sistem permainan pembelajaran tersebut. Desain UML yang akan digunakan adalah Use Case dan Activity Diagram. Berikut adalah Use Case dari aplikasi NgaBatik yang ditunjukkan pada Gambar 1. 


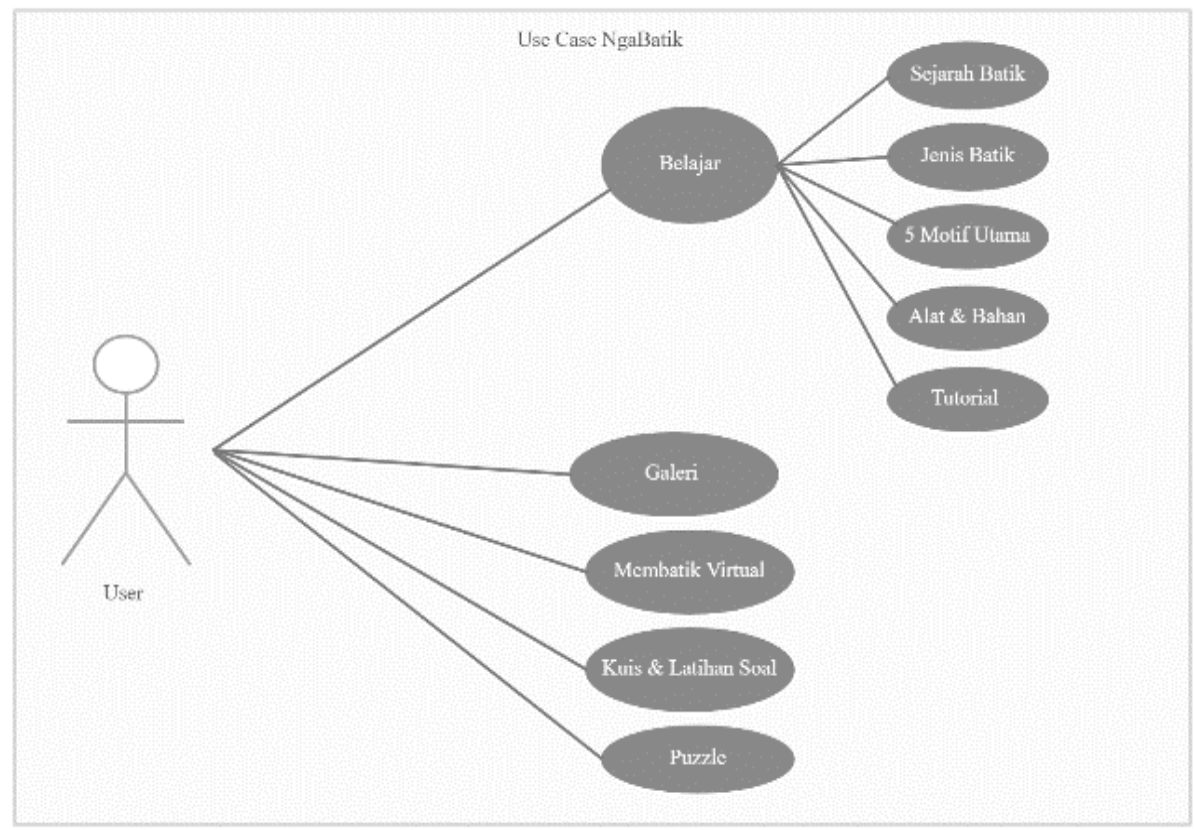

a. Activity Diagram

\section{Use Case Aplikasi NgaBatik}

Activity diagram berfungsi untuk menggambarkan seluruh aktifitas pengguna dalam sistem yang dirancang, bagaimana alur berawal, percabangan yang terjadi dan dimana alur berakhir. Diagram aktifitas juga dapat menggambarkan proses paralel yang mungkin akan terjadi pada sistem seperti berikut ini:

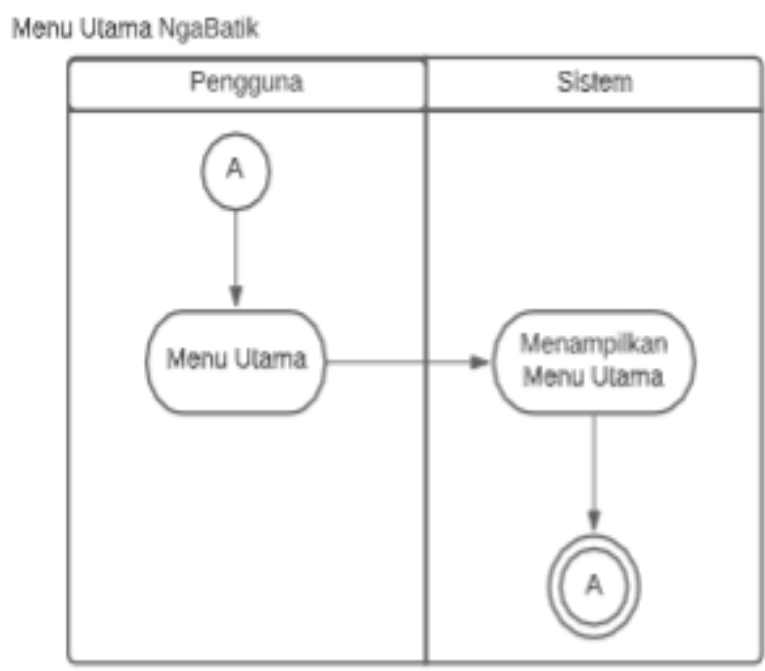

1. Activity Diagram Menu Utama 
Gambar 2

Activity Diagram Menu Utama

2. Activity diagram menu Belajar

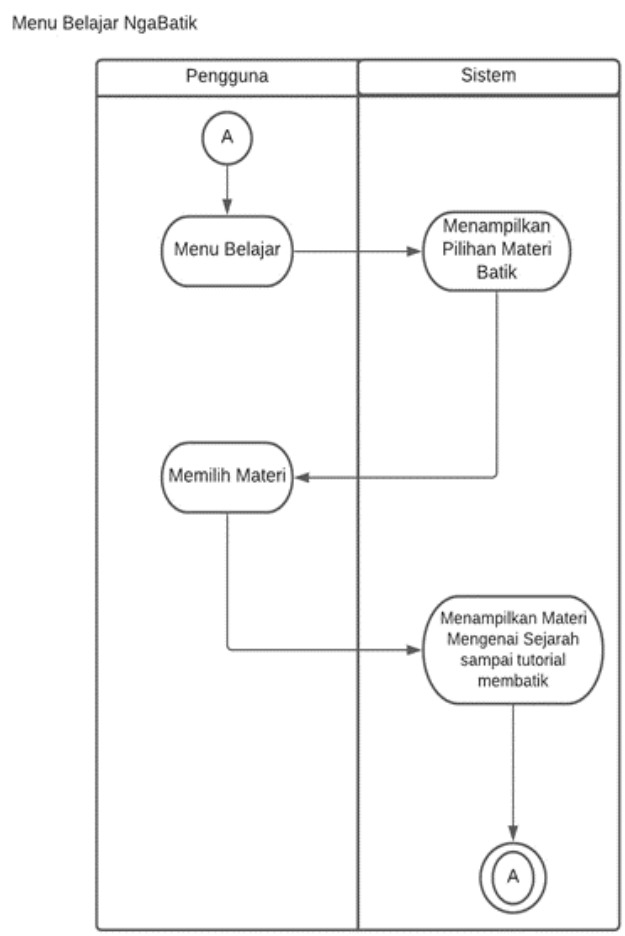

Gambar 3

Activity Diagram Menu Belajar 
Devie Febriansari dan Idam Ragil Widianto Atmojo

3. Activity diagram menu Galeri

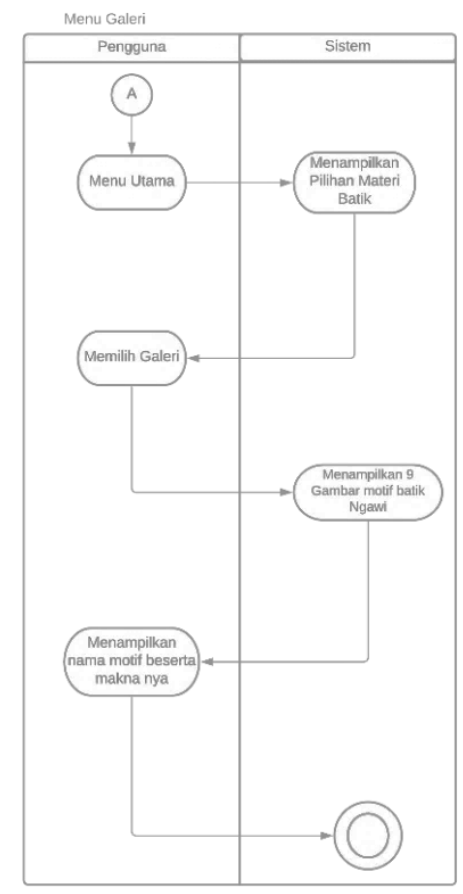

Gambar 4

Activity Diagram Menu Galeri

4. Activity diagram menu Membatik Virtual

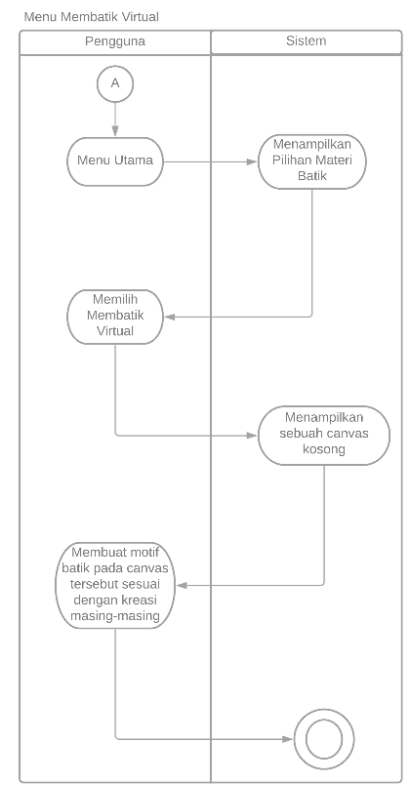

\section{Gambar 5}

Activity Diagram Menu Membatik Virtual 
5. Activity diagram menu Latihan dan Soal

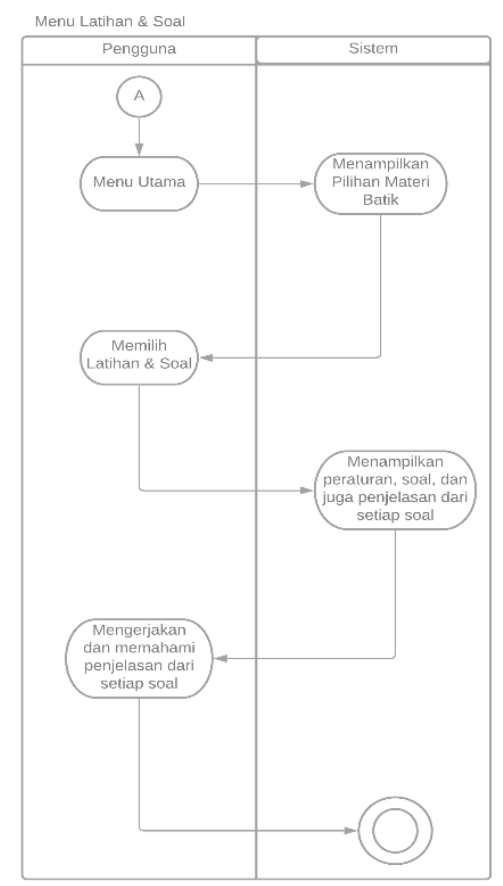

Gambar 6

Activity Diagram Menu Latihan dan Soal

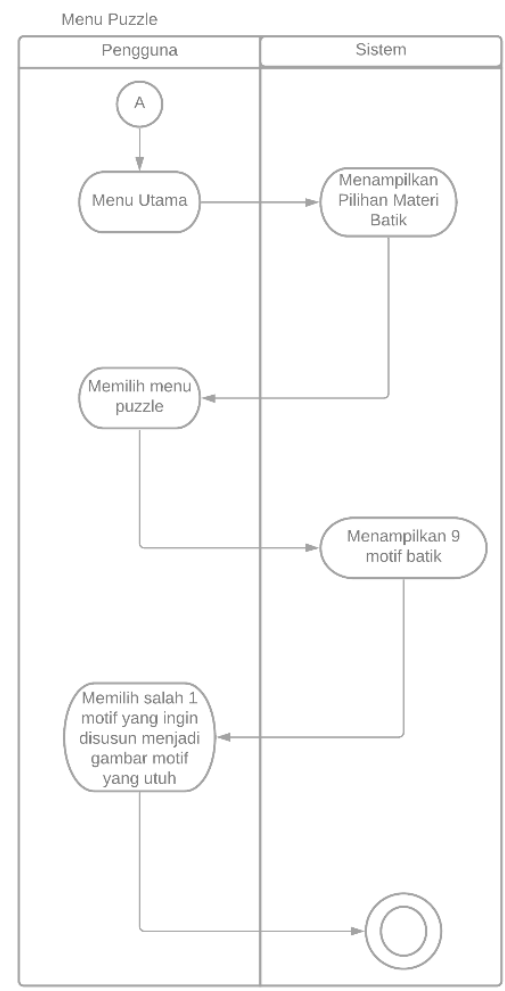

6. Activity diagram menu Puzzle

Gambar 7

Activity Diagram Menu Puzzle 
b. Pengujian

Dalam perancangan pengujian aplikasi NgaBatik ini akan diuji dengan metode Blackbox Testing. Blackbox testing adalah tes/pengujian yang berorientasi pada fungsionalitas yaitu perilaku dari perangkat lunak atas input yang diberikan pengguna sehingga mendapatkan/menghasilkan output yang diinginkan tanpa melihat proses internal atau kode program yang diproses oleh software (Febiharsa et al., 2018).

Dalam uji ini, penulis menggunakan functional testing jenis system testing untuk melihat apakah fungsi atau fitur aplikasi NgaBatik dapat digunakan dan berjalan lancar oleh pengguna. Selain itu juga menggunakan NonFunctional Testing untuk menguji apakah tiap fitur menu dan tombol dapat dioperasikan pada perangkat android. Pengujian ini dilakukan untuk memastikan fungsi aplikasi dapat berjalan dengan baik dan mencari kesalahan dari tiap-tiap eksekusi aplikasi sebelum dilakukan uji coba lebih lanjut.

Selain itu ada 2 poin penting yang perlu diuji pada saat aplikasi akan dirilis. Berikut ini poin-poin yang akan diuji:

1. Uji Materi

Uji materi merupakan pengujian untuk melihat apakah materi yang ditampilkan sudah sesuai dengan sejarah dan motif batik yang ada di Kabupaten Ngawi.

2. Uji Kelayakan Kepada Peserta didik dan Praktisi Pembelajaran

Pengujian kelayakan terhadap peserta didik dan praktisi pembelajaran dilakukan untuk melihat apakah aplikasi ini layak jika dijadikan media pembelajaran atau tidak.

\section{Hasil dan Pembahasan}

Hasil implementasi sistem atau tampilan aplikasi NgaBatik akan dijabarkan dan ditampilkan bersamaan dengan data tabel uji fungsionalitasnya.

\section{A. Uji Non-Fungsionalitas (Uji tombol)}

Pada testing aplikasi menggunakan metode blackbox testing yang bertujuan untuk memastikan fungsi tiap tombol aplikasi dan mencari eror tombol dalam aplikasi tersebut.

\section{B. Uji Fungsionalitas (Uji Sistem)}

Pengujian berikutnya adalah uji fungsional sistem. Uji sistem juga menggunakan metode blackbox testing yang lebih bertujuan untuk memastikan fungsi sistem aplikasi dan mencari error dalam aplikasi tersebut berkaitan dengan proses sinkronisasi, dan keamanan aplikasi karena NgaBatik termasuk aplikasi yang dilimitasi penggunaanya berdasarkan akun email dan password. Berikut beberapa tes fungsionalitas yang dilakukan terhadap aplikasi NgaBatik dapat dilihat pada Tabel 1. 
Tabel 1

Hasil Uji Fungsional sistem

\begin{tabular}{cll}
\hline No & Nama & Status \\
\hline $\mathbf{1}$ & Installasi program pada ponsel Android & OK \\
$\mathbf{2}$ & Masuk tampilan Halaman Log in & OK \\
$\mathbf{3}$ & Masuk Halaman Registrasi & OK \\
$\mathbf{4}$ & Masuk Halaman Home & OK \\
$\mathbf{5}$ & Masuk Halaman Belajar & OK \\
$\mathbf{6}$ & Masuk Halaman Galeri & OK \\
$\mathbf{7}$ & Masuk Halaman Membatik Virtual & OK \\
$\mathbf{8}$ & Masuk Halaman Kuis dan Latihan Soal & OK \\
$\mathbf{9}$ & Masuk Halaman Bermain Puzzle & OK \\
$\mathbf{1 0}$ & Masuk Halaman Fitur & OK \\
$\mathbf{1 1}$ & Masuk Halaman Tentang Aplikasi & OK \\
$\mathbf{1 2}$ & Log in dan Log out & OK \\
$\mathbf{1 3}$ & Edit Profil dan data diri Pengguna & OK \\
$\mathbf{1 4}$ & Melihat social media NgaBatik & OK \\
\hline
\end{tabular}

\section{Implementasi Sistem}

Pengujian fungsional bertujuan untuk mengetahui aplikasi dapat berjalan dengan baik pada perangkat android.

1. Halaman Menu Utama

Tampilan pada halaman utama pada aplikasi permainan Ngabatik berisi beberapa icon seperti icon belajar, galeri, membatik virtual, kuis, latihan soal serta bermain puzzle. Antarmuka halaman menu utama dapat dilihat pada gambar dibawah ini:
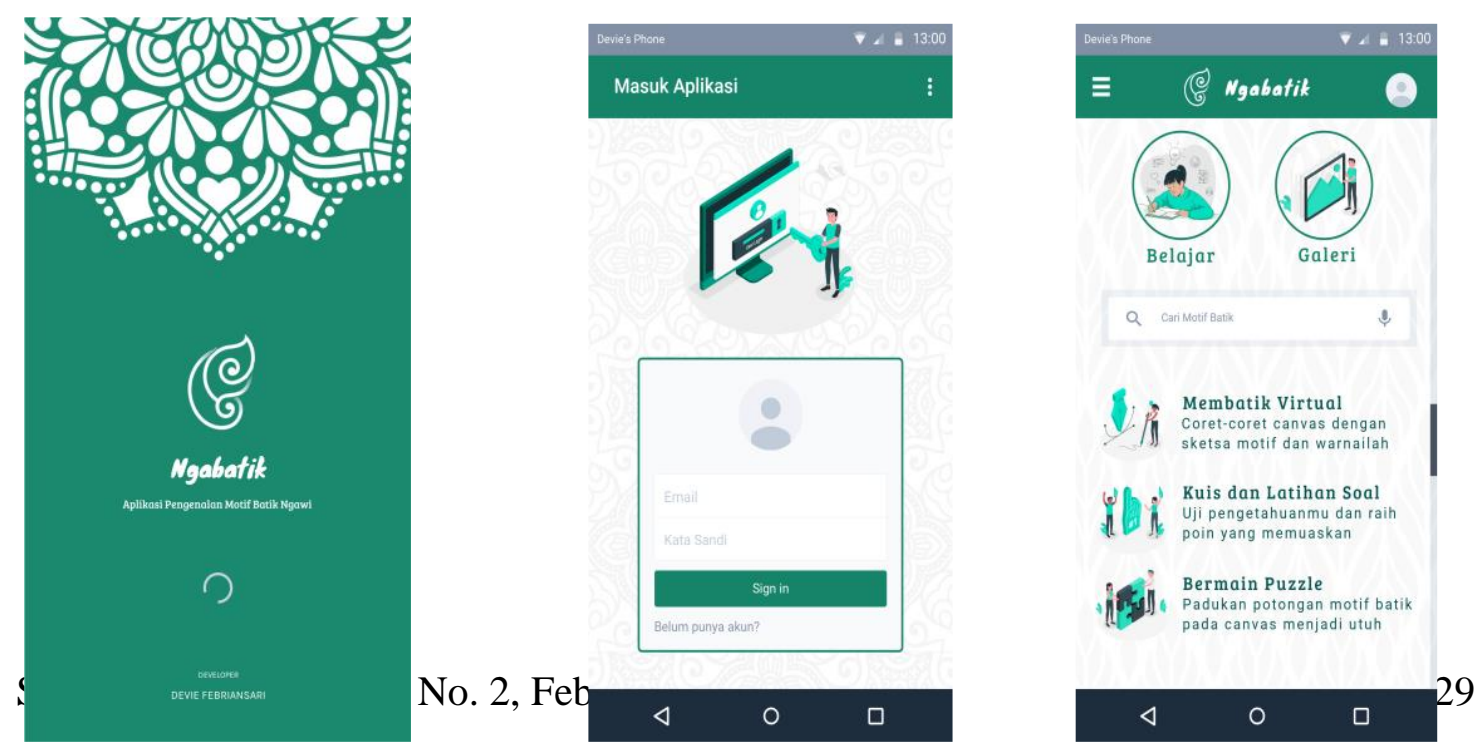

No. 2, Feb 


\section{Gambar 8}

Activity Diagram Menu Utama

2. Halaman Menu Belajar

Pada halaman menu Belajar terdapat beberapa fitur yang dapat dipilih oleh pengguna. Gambar dibawah ini merupakan antarmuka halaman pilih fitur. Pada halaman ini terdapat lima fitur seperti sejarah batik, jenis batik, 5 motif utama batik di Kabupaten Ngawi, alat dan bahan, serta video tutorial membatik .
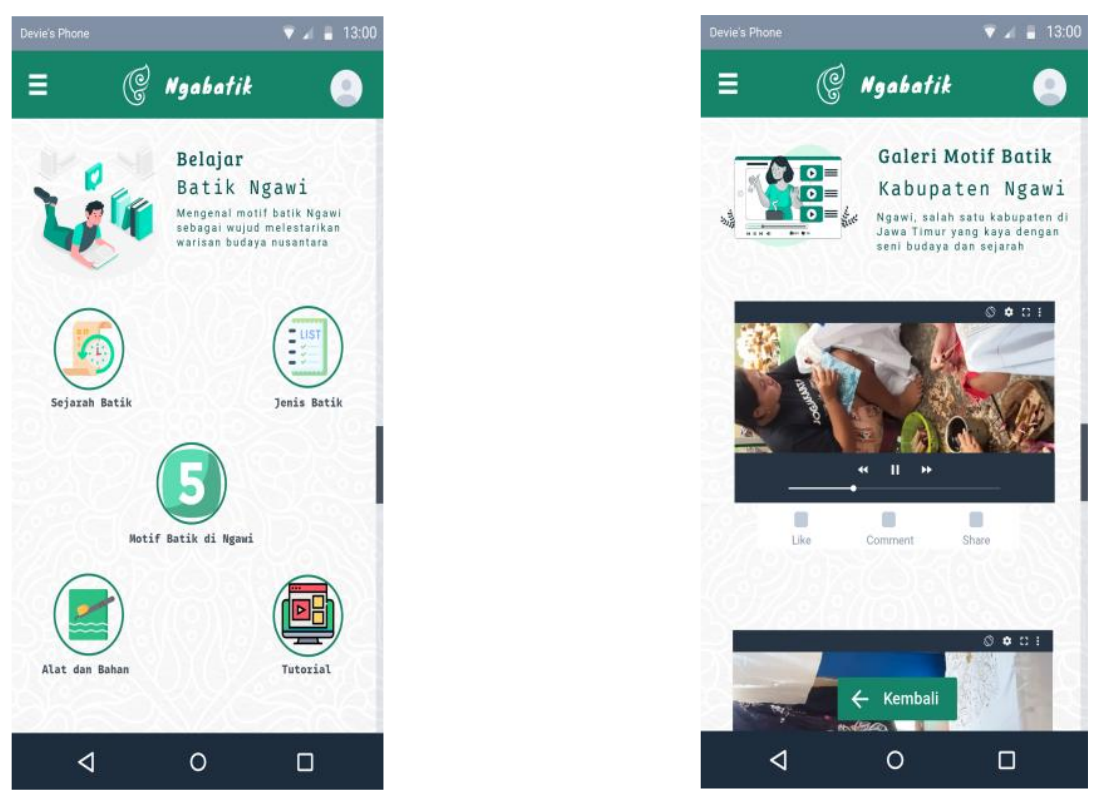

\section{Gambar 9}

\section{Activity Diagram Menu Belajar}

3. Halaman Menu Galeri Motif Batik

Pada halaman menu Galeri Motif Batik menampilkan 9 motif batik yang ada di Kabupaten Ngawi. Tampilan memilih motif yang akan dilihat 
pemaknaannya. Setelah motif dipilih langkah selanjutnya adalah membaca pemaknaan dan juga nama dari setiap motif.
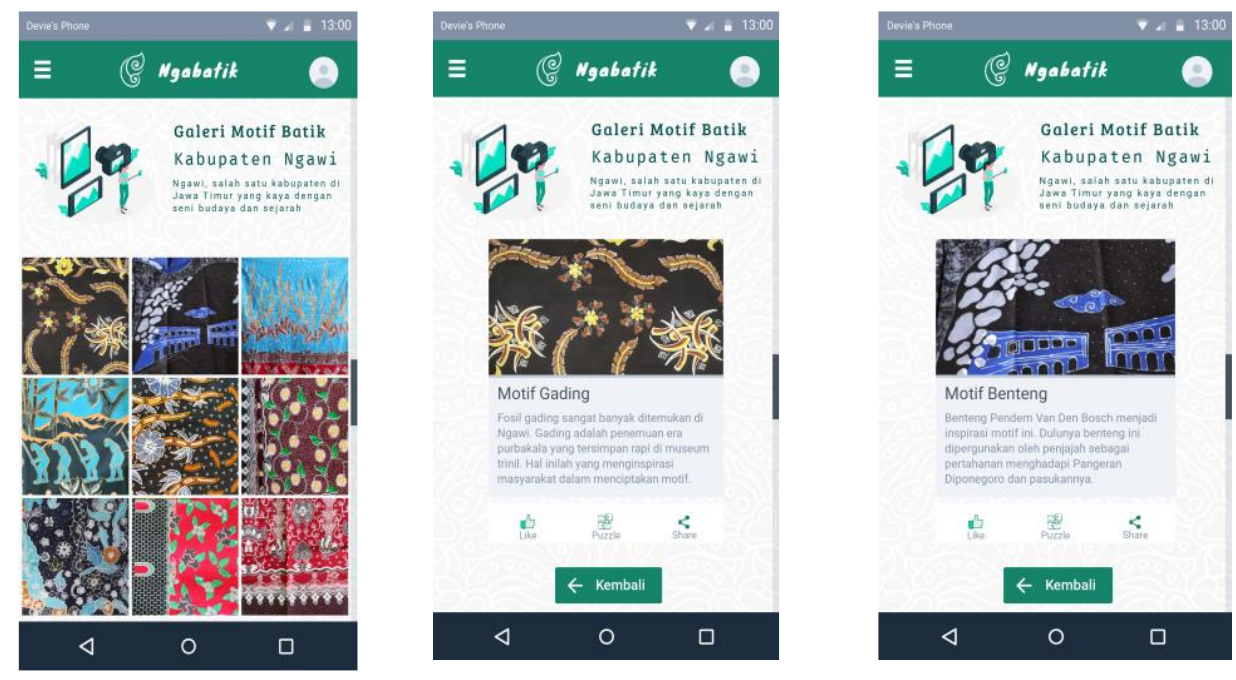

\section{Gambar 10}

\section{Activity Diagram Menu Galeri Motif Batik}

4. Halaman Menu Membatik Virtual

Pada halaman menu Membatik Virtual disediakan sebuah canvas yang nantinya pengguna dapat menggunakan itu sebagai tempat untuk menggambar dan mewarnai motif batik secara virtual, tampilan awal merupakan layer tidak penuh, dan jika pengguna ingin menggunakan layar penuh maka canvas akan menyesuaikan inch dari setiap pengguna.

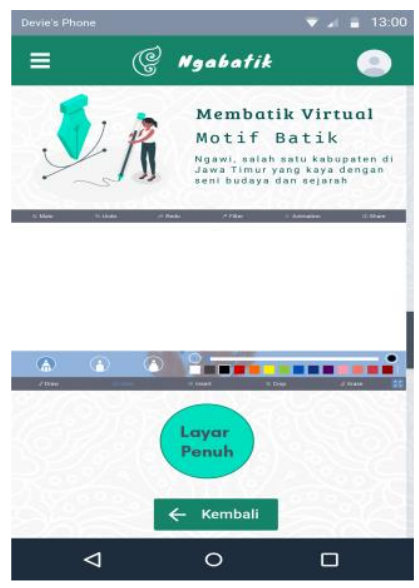

Gambar 11
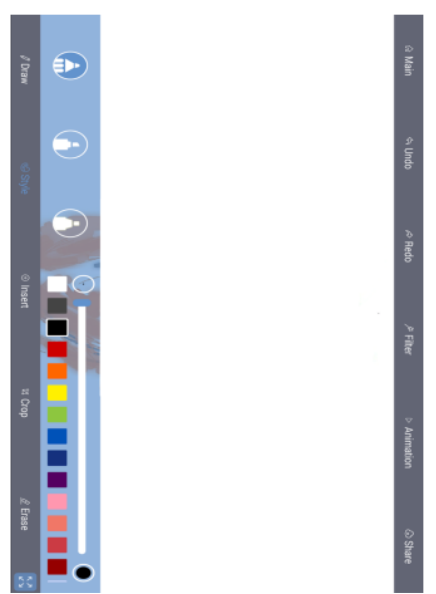

Activity Diagram Menu Membatik Virtual 
5. Halaman Menu Kuis dan Latihan Soal

Pada halaman menu Kuis dan Latihan Soal terdapat soal-soal mengenai sejarah, alat dan bahan, serta jenis-jenis motif batik khususnya di Kabupaten Ngawi. Kuis dan Latihan Soal dibuat agar pengguna bisa lebih memahami materi yang ada pada aplikasi ini.
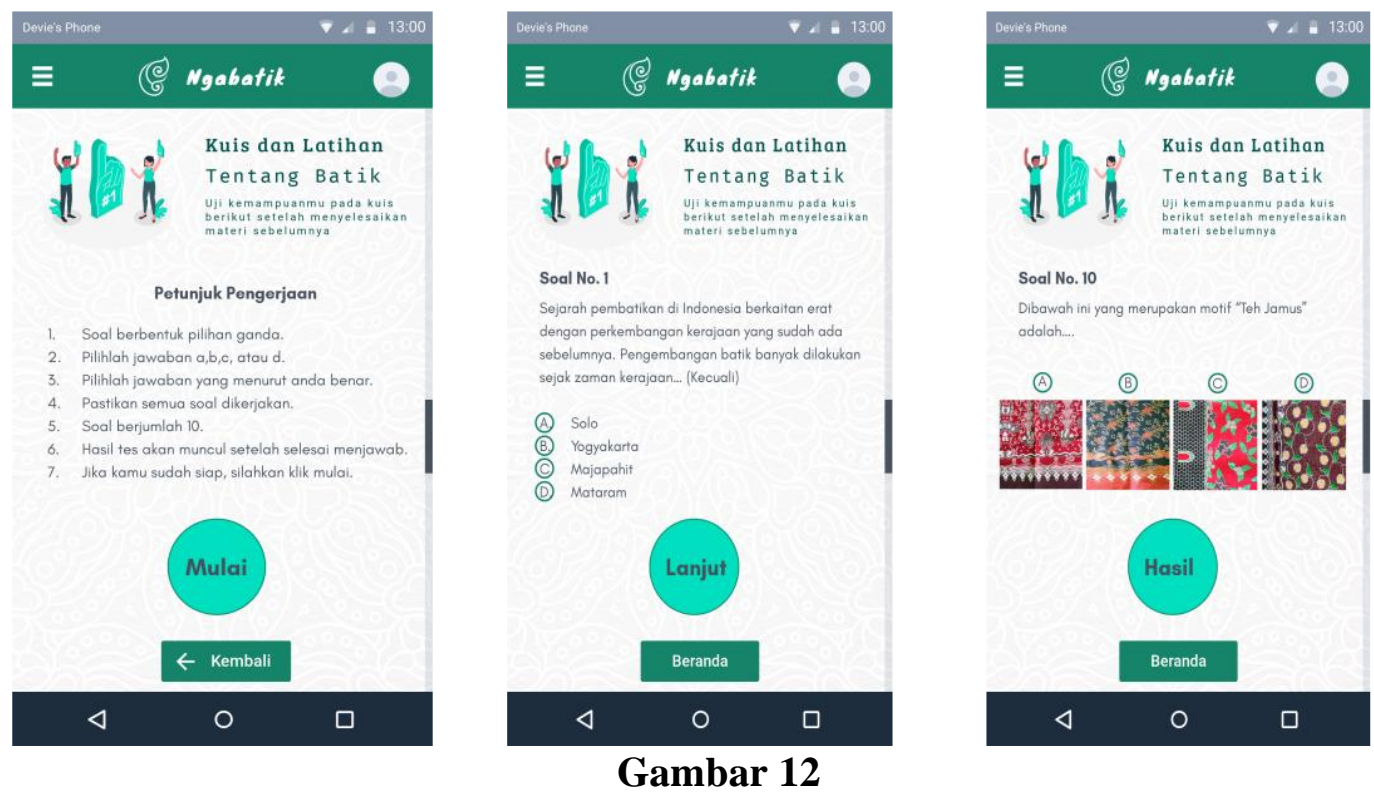

Activity Diagram Menu Kuis dan Latihan Soal

6. Halaman Menu Puzzle Motif Batik

Pada halaman menu Puzzle Motif Batik terdapat 9 pilihan motif. Setelah pengguna memilih salah satu motif maka akan muncul tampilan potonganpotongan motif dan nantinya pengguna diminta menggabungkan potonganpotongan tersebut menjadi sebuah motif yang utuh.
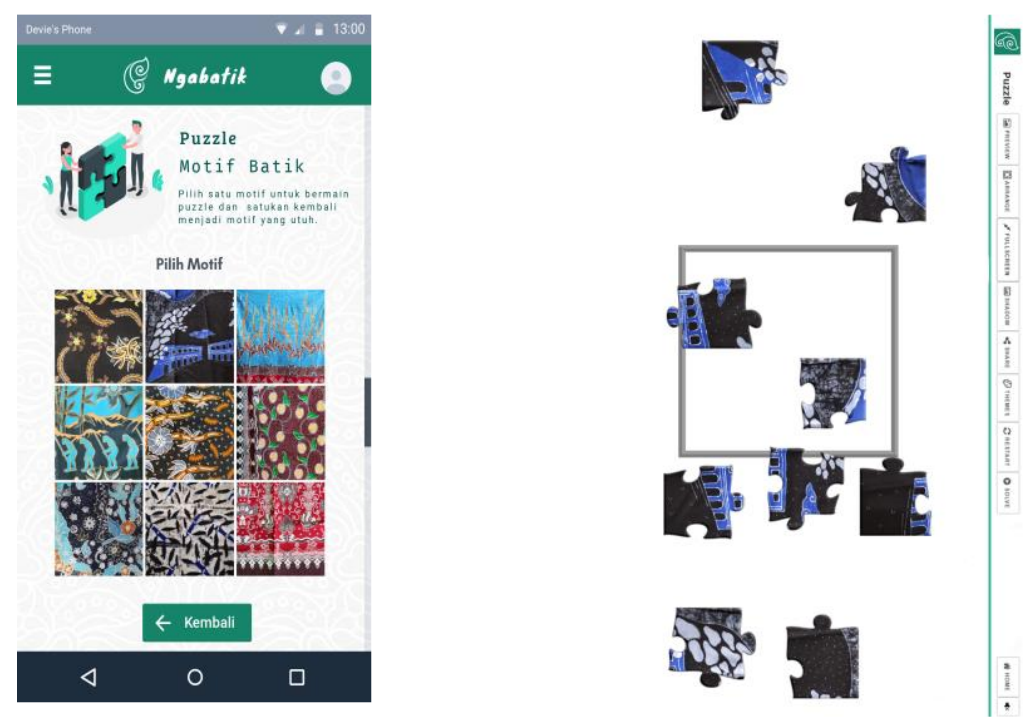

\section{Gambar 13}




\section{Activity Diagram Menu Puzzle}

7. Halaman Menu NgaBatik

Pada halaman menu NgaBatik terdapat beberapa pilihan menu yang bisa dilihat oleh pengguna yaitu: fitur, pengaturan, tentang aplikasi, kontak developer, sosial media Ngabatik, dan beri nilai aplikasi.

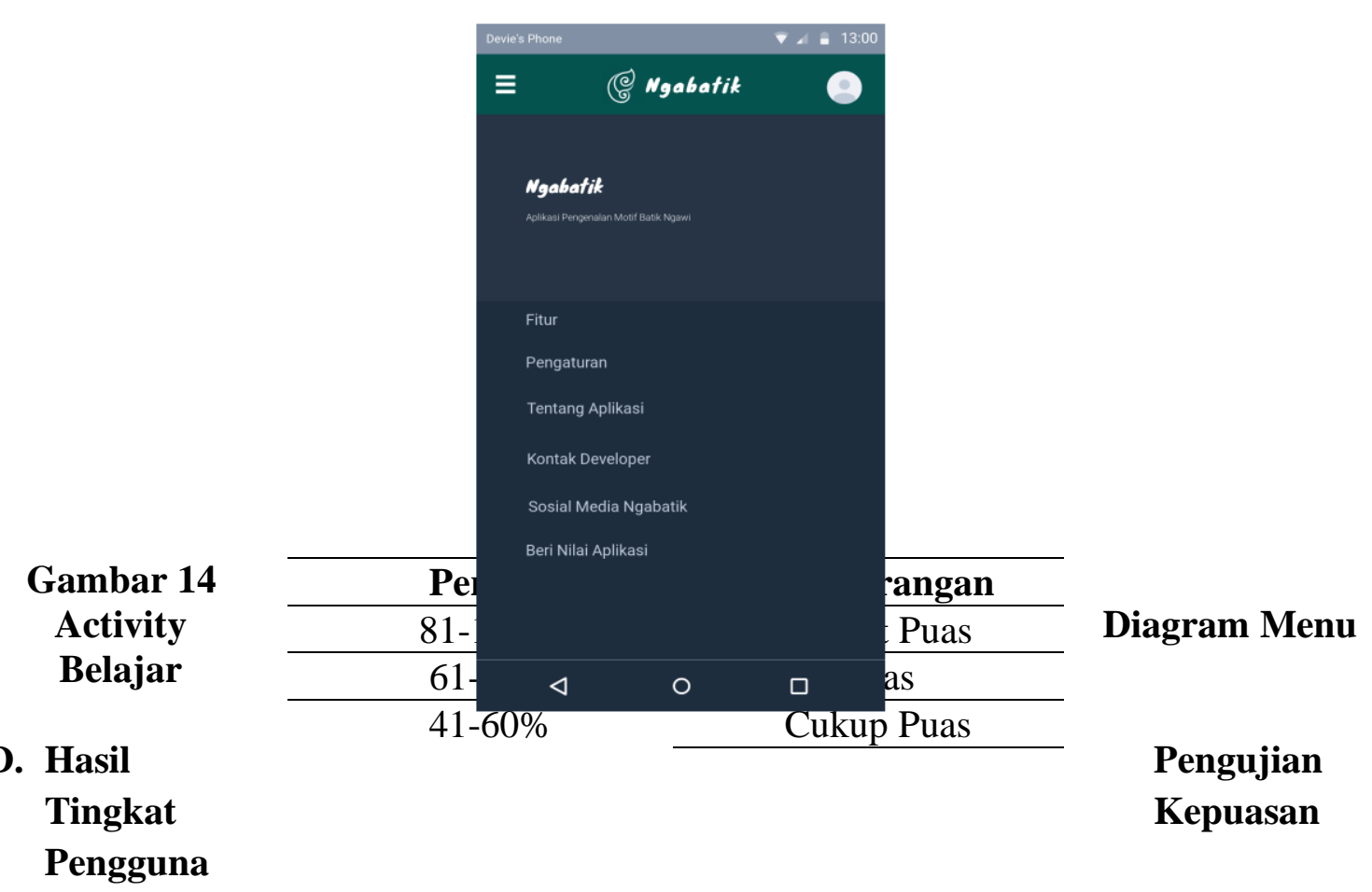

Untuk dapat mengetahui tingkat kepuasan pengguna, maka akan dilakukan uji coba secara langsung oleh pengguna. Berikut beberapa aspek yang menjadi bahan pertimbangan tingkat kepuasan pengguna yang dapat dilihat pada:

Tabel 2

\section{Aspek Tingkat Kepuasan Pengguna}

\begin{tabular}{cc}
\hline Kode & Aspek \\
\hline A & Apakah penyampaian materi dalam media ini dikemas dengan \\
menarik?
\end{tabular}

Tabel 3

Indikator Penilaian 
Devie Febriansari dan Idam Ragil Widianto Atmojo

\begin{tabular}{cc}
\cline { 2 - 2 } $21-40 \%$ & Kurang Puas \\
\hline $0-20 \%$ & Tidak Puas \\
\hline
\end{tabular}

Tabel 4

Indikator Kepuasan Pengguna

Berdasarkan pengukuran tingkat kepuasan pengguna dengan menggunakan metode kuesioner yang diberikan kepada 10 responden,

Jumlah nilai maksimal indikator penilaian $=100$ Jumlah responden yang mengisi kuesioner $=10$. Total nilai maksimal $=100 \times 10=1000$.

Presentase Kepenggunaan (\%)

$$
\begin{gathered}
\frac{\text { Total Nilai Responden }}{\text { Total Kepuasan Maksimal }} \times 100 \% \\
\frac{809}{1000} \times 100 \%=80,9 \%
\end{gathered}
$$

\begin{tabular}{|c|c|c|c|}
\hline \multirow{2}{*}{ Berdasarkan } & & & \multirow{3}{*}{$\begin{array}{lr}\text { hasil } & \text { pengukuran } \\
\text { pengguna, } & \text { dapat }\end{array}$} \\
\hline & Indikator & Nilai & \\
\hline kepuasan & Tidak Setuju & 1 & \\
\hline kesimpulan & Kurang Setuju & 2 & 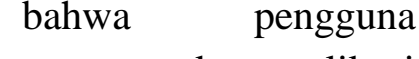 \\
\hline sangat & Cukup & 3 & nakan aplik \\
\hline engenalan mot & Setuju & 4 & Ngabatik" \\
\hline kepuasan & Sangat Setuju & 5 & $\operatorname{sar} 80,9 \%$. \\
\hline
\end{tabular}

\section{Kesimpulan}

Aplikasi Ngabatik merupakan aplikasi pengenalan motif batik digital yang memerlukan koneksi internet untuk bisa dioperasikan oleh pengguna. Aplikasi ini berbasis android application yang mana telah diuji sistem dan fungsi tombolnya sehingga siap dikembangkan dan diuji lebih lanjut pada perangkat minimal spesifikasi android lollipop 5.0. Berdasarkan pembahasan sebelumnya dapat disimpulkan bahwa pengujian sistem yang menggunakan metode blackbox testing menampilkan hasil tidak adanya error case. Kemudian, dalam uji tombol seluruhnya juga menampilkan hasil seperti yang diharapkan. 
Hasil kepuasan pengguna dengan menggunakan kuisioner menunjukkan tingkat kepuasan pengguna sebesar 80,9\% yang berarti aplikasi sangatlah memuaskan dimata penggunanya. Disarankan dalam maintenance dan upgrading aplikasi NgaBatik versi pengembangan selanjutnya diperlengkap dalam fitur-fitur penggunaannya. Selain itu dapat dibuat fitur baru seperti tempat-tempat di daerah kabupaten Ngawi yang menyediakan jasa pembuatan batik, serta kontak para pengrajin batik sehingga para pengguna tidak perlu jauh-jauh untuk pergi ke Kabupaten Ngawi jika berminat dengan batik tersebut. Kedepannya NgaBatik diharapkan mampu menjadi base aplikasi program pengadaan sistem pengenalan motif batik diseluruh provinsi yang ada di Indonesia.

\section{BIBLIOGRAFI}

Anisa, R., \& Rachmaniar, R. (2019). Media Informasi Dan Komunikasi Pemerintah Provinsi Jawa Barat. Lontar: Jurnal Ilmu Komunikasi, 7(1), 36-40.

Ardhianto, T. (2013). Aplikasi Pengenalan Batik Indonesia Berbasis Mobile Android. Universitas Muhammadiyah Surakarta.

Arifianto, T. (2011). Membuat Interface Aplikasi Android Lebih Keren Dengan Lwuit (1st Ed.). Andi Publisher.

Febiharsa, D., Sudana, I. M., \& Hudallah, N. (2018). Uji Fungsionalitas (Blackbox Testing) Sistem Informasi Lembaga Sertifikasi Profesi (Silsp) Batik Dengan Appperfect Web Test Dan Uji Pengguna. Joined Journal, 1(2), 117-126. 
Devie Febriansari dan Idam Ragil Widianto Atmojo

Handriyantini, E. (2009). Permainan Edukatif Berbasis (Educational Games) Berbasis Komputer Untuk Siswa Sekolah Dasar. Konferensi Dan Temu Nasional Teknologi Informasi Dan Komunikasi Untuk Indonesia, 2009(November 2015), 130.

Istiqomah. (2020). Pengembangan Batik Bermotif Local Wisdom Dalam Upaya Peningkatan Pendapatan Masyarakat Di Kabupaten Ngawi. Jurnal Pengabdian Dan Pengembangan Masyarakat, 4(1).

Jasmadi. (2008). Panduan Menyusun Bahan Ajar Berbasis Kompetensi. Elex Media Komputindo.

Kusumawardhani. (2013). Game Edukasi Membatik Dan Rancang Busana Batik "Ayo Mbatik!". Jurnal Ilmiah Stmik Amikom Yogyakarta, 50(5).

Parmono, K. (2013). Nilai Kearifan Lokal Dalam Batik Tradisional Kawung. Jurnal Filsafat, 23(2), 134-146.

Parmono, K. (2017). Simbolisme Batik Tradisional. Jurnal Filsafat, 1(1), 28-35.

Pranowo, G. (2011). Kerasi Animasi Interaktif Dengan Action Script 3.0 Pada Flash Cs5 (A. Prabawali (Ed.)). Yogyakarta: Andi, 2011.

Rauhandi. (2011). Analisis Dan Perancangan Game Edukasi “ Ayo Membatik " Menggunakan Adobe Flash. Jurnal Dasi, 12(4).

Rosyadi, A., Sunarya, E., \& Komariah, K. (2020). Komunikasi Pemasaran Sebagai Upaya Pelestarian Kain Batik Sukabumi. Syntax Idea, 2(10), 738-748.

Stojšić, I., Ivkov-Džigurski, A., \& Marǐić, O. (2019). The Readiness Of Geography Teachers To Use Mobile Devices In The Context Of Immersive Technologies Integration Into The Teaching Process. Geographica Pannonica, 23(2), 122-134. Https://Doi.Org/10.5937/Gp23-20762

Wibowo, J., Tanuwijaya, H., \& Fianto, A. Y. A. (2016). Lp: Rancang Bangun Management Information System Batik Tradisional Jawa Timur Sebagai Upaya Pelestarian Warisan Budaya Bangsa. Penelitian Dan Pengembangan Stikom Surabaya. 